\title{
MODALITĂŢI DE CATEHIZARE A STUDENŢILOR. MODELE ŞI EXPERIENŢE ALE UNIVERSITĂŢII DE STAT DIN MOLDOVA
}

Octavian Moşin *

\begin{abstract}
Nowadays there is a crisis in the pastoral activity among the young generations. We have dynamic and restive young people eager to know Christ. Or, the church had always the mission to bring closer God to people. To know God, means to show or to manifest the common belief!
\end{abstract}

Keywords: church, belief, love, youth, truth, orthodox, conferral.

\section{Preliminarii}

Catehizarea copiilor şi a tinerilor dintotdeauna a avut un loc însemnat în lucrarea misionar-pastorală a creştinismului. De-a lungul timpului, Capela „Întâmpinarea Domnului” din cadrul Universităţii de Stat din Moldova, a avut un rol important în educarea şi formarea elevilor, studenţilor şi în general al tinerilor. Capela „Întâmpinarea Domnului" din momentul ctitoririi sale (1879-1880) şi până în zilele noastre reprezintă un lăcaş de reculegere pentru elevi, studenţi şi cadrele didactice din instituţiile de învăţământ pe lângă care a funcţionat şi funcţionează.

Biserica reprezintă un pilon important în formarea duhovnicească a studenţilor, oferind un model de conduită în persoana preoţilor şi enoriaşilor din biserică. Rolul Bisericii este, pe de o parte, să-i menţină nealteraţi pe tineri de concepţia unei lumi fără Dumnezeu, iar pe de altă parte, să ofere soluţii şi tratamente celor care s-au rănit deja. Prin metodele ei pedagogice Biserica îi ajută pe tineri să conştientizeze responsabilitatea pe care o au faţă de consecinţele faptelor lor. Biserica urmăreşte să dezvolte la tineri virtutea iubirii, iubire care nu este îndreptată numai spre cei dragi, ci şi spre aproapele nostru. Un rol

${ }^{*}$ PhD, Associate Professor, Moldavia State University, Chisinau, Moldavia. 
important în acest sens a revenit preoţilor slujitori în cadrul Capelei. În majoritatea cazurilor preotul a jucat rolul unui îndrumător spiritual pentru tineri. El îşi asuma această misiune de călăuză spirituală, de luminător şi sfătuitor al sufletelor plăpânde ale tinerilor.

\section{Educaţie şi cateheză în spaţiul studenţesc laic}

Un rol important în catehizarea tinerilor îl are preotul, care ulterior devine duhovnicul lor. Această idee este confirmată şi de Părintele Ilie Sârbu, care afirmă că preotul de astăzi nu poate să fie mulţumit doar de cunoaşterea perfectă a tipicului bisericesc. Astăzi, preotul este chemat şi la o intensă activitate - catehetică, antisectară, social-caritativă etc. Toate acestea şi multe altele au devenit deja părţi necesare şi cerinţe importante în viaţa bisericească, pentru mântuirea neamului creştinesc şi în folosul societăţii, care zilnic este provocată şi încercată.

Dar pentru realizarea lucrării catehetice, preotul trebuie să se întoarcă la modelul şi chipul viu - Marele Învăţător şi Catehet, Domnul nostru Iisus Hristos. Hristos, spune părintele Ilie, a avut multe de transmis oamenilor şi lumii, dar a ştiut să se facă ascultat, înţeles, iubit şi urmat. Acest fapt se datorează dragostei şi păcii, aduse de către Mântuitorul ${ }^{1}$.

Unul dintre aspectele esenţiale de slujire didactică ale preotului este prezenţa dragostei şi bunăvoirii. Preotul trebuie să cunoască mai mult decât rânduiala slujbelor şi Scriptura. Pentru a cunoaşte psihicul uman, a da un răspuns şi un sfat, a suş̧ine credincioşii în plan moral, este absolut necesar ca preotul să aibă cunoştinţe din diverse domenii ale vieţii sociale. Necesar este a studia şi pedagogia, şi psihologia, şi medicina.

Făcând comparaţie cu Mântuitorul, preotul trebuie să devină, pentru cei pe care el îi învaţă, nu numai învăţător, îndrumător, ci şi un părinte, tată, frate, prieten. Formând în jurul său o ambianţă caldă,

${ }^{1}$ Ilie Sârbu, Catehizarea copiilor şi tineretului, obiectiv prioritar al Bisericii, în „Altarul Banatului”, an. I (40), mai-iunie 1990, nr. 5-6, p. 50-57. 


\section{$15^{\text {th }}$ International Simposium on Science, Theology and Arts}

insuflând în discuţiile sale şi lecţii, şi dragoste, şi prietenie. Pentru a reuşi să ajungă la sufletul tinerilor, preotul trebuie să fie un model al vieţii creştine, prin fapte vii, prin gesturi, prin diverse acţiuni şi slujiri, să facă ,,pildă bună după dânsul”.

În acest sens, acum 4 ani s-au introdus programe de masterat cu caracter creştin în cadrul câtorva facultăţi ale Universităţii de Stat din Moldova:

- Studii filologice şi spiritualitate creştină, la Facultatea de Litere;

- Consiliere educaţională şi spirituală, la Facultatea de Psihologie şi Ştiinţe ale Educaţiei; Filozofie. ${ }^{2}$

- Istoria şi cultura religiilor, la Facultatea de Istorie şi

Peste o sută de tineri au posibilitatea să se apropie de cele sfinte şi să pătrundă în învăţătura de credinţă ortodoxă, prin prisma filologiei, istoriei şi psiho-pedagogiei.

Asociaţia Studenţilor Creştini Ortodocşi din Moldova şi implicarea sa în acţiunile culturale, educative şi filantropice din spaţiul universitar

Un rol important în catehizarea studenţilor şi tinerilor îl are implicarea în rândurile Asociaţiei Studenţilor Creştini Ortodocşi din Moldova (ASCO), creată în anul 1996. ASCO este una din primele organizaţii ortodoxe de tineret din Republica Moldova şi una din puţinele care, în pofida greutăţilor, continuă să activeze încercând să câştige teren într-un tărâm colonizat de activiştii câtorva zeci de secte şi grupări religioase.

ASCO întruneşte studenţi de la diferite instituţii de învăţământ care au ambiţia de a promova în societatea noastră secularizată valorile şi învăţătura ortodoxă. Asociaţia este, totodată, şi un loc de întâlniri pentru tinerii creştini ortodocşi, de socializare şi împărtăşire a bucuriilor şi problemelor. Biserica este locul ideal unde se pot întâlni doi tineri care cred în Domnul Cel Înviat, iar în ultimii ani cel puţin 200

${ }^{2}$ A se vedea pagina electronică: www.masterateortodoxe.blogspot.com 
de tineri şi-au găsit ,jumătatea" participând la activităţile asociaţiei în capela universităţii. În cadrul ASCO este un program săptămânal de acţiuni, care include pelerinaje la locurile sfinte, ore de catehizare. Din anul 2003, în cadrul Asociaţiei Studenţilor Creştini Ortodocşi se organizează cursuri gratuite de studiere a limbilor moderne. Sute de tineri au trecut nivelul începătorilor, însuşind engleza, germana şi italiana. În ultimii doi ani ASCO s-a limitat doar la cursurile de engleză.

Tinerii sunt implicaţi şi în domeniul asistenţei sociale, voluntarii ajutând anual circa 30 de bătrâni. De asemenea, în grija capelei sunt câtiva copii din familii vulnerabile social. Prin aceste acţiuni se încearcă să-i apropiem de cele sfinte pe copilaşi, să-i mângâiem sufleteşte atât cât vom putea şi să le cultivăm dragostea pentru Biserica strămoşească $\breve{3}^{3}$. În acest sens, un rol considerabil îl are implicarea studenţilor în activităţile desfăşurate de către Asociaţia Studenţilor Creştini Ortodocşi, care activează în cadrul Capelei „Întâmpinarea Domnului”. În fiecare săptămână se citeşte Acatistul către Sfântul Duh, de viaţă făcătorul, care este foarte folositor pentru reuşita la învăţătură, pentru luminarea minţii şi a vieţii. Apoi se desfăşoară discuţii tematice. În ultimul deceniu au fost invitaţi peste 200 de teologi, slujitori, savanţi şi oameni ai credinţei, care au transmis un mesaj ziditor de suflet pentru tineri. Aceste întruniri săptămânale cu tinerii le oferă răspunsuri la întrebările care îi preocupă, li se altoieşte dragostea şi se susţin învăţăturile creştine.

Lipsa cunoştinţelor teologice îi face adesea pe tineri extrem de vulnerabili în confruntarea cu reprezentanţii unor culte neoprotestante sau de alt gen, care posedă tehnici moderne de prozelitism. Tot mai multe grupări religioase încearcă să racoleze tineri ortodocşi pe care îi abordează nestingherit chiar în aulele universitare. Astfel, prin activităţile propuse, tinerilor li se explică de ce trebuie să rămână în Biserica lui Iisus Hristos, care este Calea, Adevărul şi Viaţa. Numai

\footnotetext{
${ }^{3}$ http://tineretulortodox.md/2011/04/pr-octavian-mosin-Clucrul-cu-tineretultrebuie-sa-fie-o-prioritate-a-bisericii-ortodoxe.
} 


\section{$15^{\text {th }}$ International Simposium on Science, Theology and Arts}

Biserica şi Mântuitorul le poate împlini şi le poate oferi un scop nobil în viaţă.

În cadrul orelor de catehizare tinerii sunt foarte curioşi şi au multe întrebări la care nu pot găsi răspunsuri serioase, nici ei, nici prietenii, nici părinţii lor. Mulţi au nevoie de comunicare, pentru că se simt străini, singuratici, deoarece au alte idealuri decât cei din jurul lor. La aceste întruniri în fiecare an vin alţi şi alţi tineri, căci anii studenţiei trec repede. Important este să se ajungă la inima tânărului şi să se lase ceva bun, pentru că s-ar putea ca acest ceva să fie crucial pentru viaţa lui de creştin.

Desprinzându-se de casa părintească, tinerii nimeresc într-un mediu mai puţin cunoscut, care deseori îi atrage prin diferite promisiuni şi senzaţii, care de cele mai multe ori îi duc spre cădere şi deznădejde. Tânărul este o unealtă prin care lucrează Dumnezeu şi care are nevoie de hrană duhovnicească pentru a-şi îmbunătăţi starea lăuntrică, pe care reuşeşte să o găsească prin intermediul Bisericii. Este foarte odihnitor şi plin de speranţă pentru un student să vadă că în biserică sunt şi alţi tineri, de vârste apropiate, care au aceleaşi principii de viaţă ca ale lui. Chiar dacă se simte uneori în disonanţă cu colegii de la instituţiile de învăţământ, venind la biserică, mergând împreună în pelerinaj la mănăstiri şi implicându-se în diferite activităţi comune, tinerii observă că nu sunt singuri, că mai sunt tineri care împărtăşesc aceleaşi valori şi principii de viaţă.

\section{Capela „Întâmpinarea Domnului” - spaţiu şi mediu formativ pentru studenţi şi copii}

Capela „Întâmpinarea Domnului” încearcă să ofere tinerilor acest mediu în care să se regăsească şi să-şi manifeste dragostea şi înţelegerea faţă de aproape. Valorile cultivate şi virtuţile încurajate în cadrul bisericii sunt necesare sănătăţii spirituale a persoanei şi a comunităţii. Valorile cultivate sunt extrem de necesare, mai ales în această perioadă de secularizare a societăţii, întrucât ele reprezintă pentru tineri un reper spiritual esenţial. Prin rolul ei formativ în viaţa tinerilor, Biserica oferă tinerilor repere în viaţa de familie şi în 
societate. Prin implicarea studenţilor în activităţile desfăşurate în cadrul bisericii, tinerilor li se cultivă responsabilitatea, dragostea, respectul, înţelegerea, răbdarea, smerenia şi bunăvoinţa. În perioada vacanţei în cadrul Capelei se organizează tabere pentru copii, în cadrul cărora studenţii au rolul de educatori, formatori şi promotori ai valorilor general-umane.

Biserica „Întâmpinarea Domnului” pe lângă faptul că reprezintă un element important în educarea şi formarea duhovnicească a studenţilor, în constituirea unor relaţii între membrii comunităţii, bazate pe stimă şi respect reciproc, are şi rolul de a păstra unitatea morală şi spirituală a tinerilor, care este supusă la grele încercări. Iniţial, studenţii erau invitaţi după ore la capelă, însă ajungeau mai puţin de jumătate. Astfel, s-a decis ca slujitorii şi tinerii îmbisericiţi să meargă prin universitate, în sălile de curs, unde se simt mai bine, mai siguri. Aproximativ şaptezeci la sută din ei sunt interesaţi de cele sfinte, sunt curioşi ce mesaj li se va transmite. Prin astfel de discuţii se depăşesc anumite bariere şi stereotipuri, iar ulterior îi regăsim pe unii în biserică, căutându-1 şi chiar comunicând cu Dumnezeu .

În cadrul Săptămânii Tineretului Ortodox, la USM se organizează întruniri tematice în cadrul fiecărei facultăţi, zeci de întâlniri duhovniceşti cu invitaţi din ţară şi de peste hotare, pelerinaje la sfintele mănăstiri, acte de caritate şi alte activităţi în rândul tinerilor. Studenţilor li se vorbeşte despre credinţă, drepturi şi obligaţii morale, precum şi despre sensul vieţii, raportat la moarte şi înviere. Preoţii implicaţi în aceste activităţi oferă răspunsuri la întrebările adresate de către tineri, atât personale, cât şi din cele cu care se confruntă societatea noastră. După orele de curs sunt planificate conferințe în cadrul fiecărei facultăţi.

O importantă misiune educativă și filantropică o au slujitorii de la capelă. Catehizarea şi apropierea studenţilor de Biserică se realizează prin stabilirea unui parteneriat între Universitate şi Biserică. În acest sens, se organizează pe parcursul anului de studii diverse manifestări

$4 \mathrm{http}: / /$ tineretulortodox.md/2016/04/s-a-dat-start-saptamanii-tineretului-ortodoxla-usm. 


\section{$15^{\text {th }}$ International Simposium on Science, Theology and Arts}

culturale comune, expoziţii, conferinţe cu tematică religioasă, participarea reprezentanţilor Bisericii la manifestările organizate de către universitate: deschiderea/închiderea anului de studii, sfinţirea blocurilor de studii şi a căminelor studenţeşti, organizarea pelerinajelor la diverse aşezăminte bisericești etc. Prin aceste activităţi educative studenţii sunt încurajaţi, motivaţi şi educaţi în vederea interiorizării valorilor morale.

Preotul este şi un semănător, care lucrează zilnic în grădina dumnezeiască, unde sădeşte şi creşte noi membri, fii şi fiice ale Bisericii lui Hristos. Şi dacă va pune toată căldura inimii, toată lumina minţii şi tot devotamentul de care este capabil, în opera de îndrumare a generaţiei tinere spre culmile spirituale ale Evangheliei Mântuitorului nostru Iisus Hristos, atunci lucrarea lui va atinge succesul dorit şi satisfacţia datoriei împlinite. Necesitatea de a găsi liniştea şi împăcarea lăuntrică îi adună pe tineri împreună, pentru a petrece timpul util, pentru a discuta prieteneşte, pentru a-I urma lui Hristos, cu şi prin persoana celor de alături. Asociaţia Studenţilor Creştini Ortodocşi în parteneriat cu biserica „Intâmpinarea Domnului” din incinta USM desfăşoară pe parcursul anului diverse campanii şi acţiuni speciale de caritate. De şapte ani dă roade îndemnul de a colecta la biserică bunuri pentru enoriaşi nevoiaşi, care tot de la biserică iau de ce au trebuinţă. Unii aduc, alţii iau.

O metodă de catehizare în rândul tinerilor este punerea la dispoziţie a cărţilor cu caracter religios şi învăţături creştine. Astfel, înfiinţarea Bibliotecii de carte religioasă în cadrul Universităţii de Stat din Moldova oferă tinerilor posibilitatea de a citi şi căuta răspunsuri la multe întrebări care îi preocupă. Citirea literaturii cu conţinut religiosmoral aduce folos enorm la îmbogăţirea sufletului cu hrană spirituală, atât de necesară tânărului ortodox.

O altă metodă de catehizare în rândul tinerilor o reprezintă organizarea taberelor de vară. Taberele religioase pentru copii şi tineri oferă o alternativă creştinească de petrecere a vacanţelor de vară. O tabără religioasă este o metodă prin care tinerii se apropie de Dumnezeu, se apropie unul de altul şi învaţă câteva lucruri bune. Participanţii se implică în diferite acţiuni, studii biblice, cântări, jocuri, 
drumeţii, foc de tabără, trăire duhovnicească. Tabăra creştină are ca scop dezvoltarea în rândul tinerilor a obiceiurilor ortodoxe, ca într-o mare familie creştină: cu rugăciune de dimineaţă, de seară sau înainte de masă, cu dezbateri pe diferite teme teologice şi participare la Sfânta Liturghie.

În perioada vacanţei de vară, în cadrul Bisericii „,̂ntâmpinarea Domnului" din incinta Universităţii de Stat din Moldova se organizează o tabără pentru petrecerea cu folos a timpului liber, a copiilor cu vârsta cuprinsă între 6-14 ani. Tabăra este organizată cu ajutorul tinerilor din Asociaţia Studenţilor Creştini Ortodocşi care desfăşoară diverse concursuri şi activităţi pentru implicarea copiilor în activităţi educativcreative, în funcţie de propriile opţiuni. Copiii se familiarizează cu lumea frumosului şi, pe parcursul activităţilor, îşi formează abilităţi în desen, broderie, decor, origami, ş.a. De asemenea, învaţă cântări religioase, rugăciuni, participă la concursuri de eseuri şi desen. Cei care organizează activităţile cu copiii sunt tinerii din ASCO, care îi ajuta să aibă o vacanţă frumoasă şi ziditoare.

Studenţii sunt implicaţi în organizarea unor acţiuni de caritate (Campania ingerilor, Faptele bune pot fi şi dulci), familiarizarea persoanelor necunoscătoare cu valorile şi sărbătorile creştin-ortodoxe (ieşiri în parc, distribuire de flori sau pliante, promovarea valorilor naţionale).

Un rol deosebit în apropierea tinerilor de valorile morale 1-a avut organizarea taberei de vară: La baştina Părintelui Sofian Boghiu Cuconeştii Vechi $2015^{5}$, organizată de către Asociaţia cultural-istorică „Noua Galilee” în colaborare cu Asociaţia Studenţilor Creştini Ortodocşi din Republica Moldova. Tabăra s-a desfăşurat în apropierea malurilor pitoreşti ale Prutului (s. Cuconeştii Vechi, r. Edineţ) şi a oferit celor peste 40 de participaţi posibilitatea să desfăşoare diverse activităţi precum ateliere de istorie, de cultură, de muzică bisericească ş.a. Pe parcursul taberei, tinerii au avut ocazia să descopere frumuseţile naturii, să viziteze monumentele istorice şi împrejurimile. Participanţii

5 http://ineretulortodox.md/2015/08/in-perioada-7-9-august-s-a-desfasurat-inpremiera-tabara-de-vara-la-bastina-parintelui-sofian-boghiu-cuconestii-vechi. 
la tabără s-au familiarizat cu personalitatea şi activitatea vrednicului de pomenire părinte Sofian Boghiu, originar din Cuconeştii Vechi. Totodată, tinerilor li s-a vorbit despre credinţa strămoşească şi tradiţiile înaintaşilor.

\section{Pastoraţia în spaţiul universitar şi nevoia de valorificare a entuziasmului tinerilor}

Biserica trebuie să ofere tânărului modele vii de credincioşi împliniţi duhovniceşte, pentru ca el să se simtă încurajat în demersul său spiritual. Tinerii participă la viaţa liturgică şi la cultul divin prin învăţarea, inclusiv în cadrul catehezelor, a unor cântări religioase (colinde, cântări pascale, alte cântări din cadrul Sfintei Liturghii şi a altor slujbe bisericeşti).

Parohia, ca celulă a comunităţii creştine, este datoare să vină în întâmpinarea nevoilor şi preocupărilor acestei vârste, prin natura ei deschisă spre tot ce este nou. Astfel, să oferim tinerilor oportunităţi de care aceştia au nevoie, pentru creşterea lor spirituală, dar pe care nu le pot accesa întotdeauna prin ei înşişi. În acest sens îi implicăm pe tineri în diverse proiecte sociale, cum ar fi: activităţi antitrafic, antidrog, contra violenţei, antituberculoză, antitutun etc., toate bazate pe voluntariat. Pentru că, aşa cum spunea părintele Dumitru Stăniloae; „decât să stau degeaba, mai bine muncesc degeaba”. Tinerii se implică în activităţile organizate de ASCO.

Ei sunt cei care joacă rolul de mentori şi educatori în cadrul taberei de vară cu sejur de zi pentru copii, vizitează pe cei săraci şi pe cei bătrâni, pe persoanele cu diferite probleme de sănătate, socializează şi le dau o mână de ajutor. Astfel, învaţă să ofere dragoste şi ajutor celor apropiaţi, învaţă smerenia şi răbdarea. Toate acestea îi ajută să devină şi ei înşişi un bun exemplu pentru alţi tineri. Şi astfel acei tineri care s-au apropiat de biserică şi învăţăturile Mântuitorului realizează ulterior activităţi de catehizare a copiilor.

Pastoraţia realizată împreună cu tinerii înseamnă a le da acestora şansa de a participa activ la viaţa comunităţii. Aceasta este eficientă atunci când sunt implicaţi ei înşişi în activităţi dedicate slujirii 
celorlalţi. Participarea la programe de consiliere împotriva consumului de droguri şi a alcoolismului, implicarea în activităţi de catehizare a copiilor, organizare de conferinţe şi cursuri, acţiuni de ajutorare a bătrânilor, organizarea unor expoziţii şi spectacole de conservare a tradiţiilor, constituie exemple de pastoraţie a tinerilor realizată chiar de tineri. Tinerii, speranța Bisericii, sunt cei mai în măsură să apere ultimele redute ale creştinismului ortodox. Prin puterea şi entuziasmul lor, misiunea preoţilor devine mult mai uşoară ${ }^{6}$.

În întâmpinarea şi la dorinţa tinerilor a fost înfiinţată şi Mişcarea Tineretului Ortodox, care îşi propune să unească creştinii ortodocşi, în special generaţia tânără, din întreaga ţară prin intermediul cât mai multor activităţi organizate atât la nivel naţional, cât şi local. Mişcarea Tineretului Ortodox a organizat o serie de acţiuni, în cadrul cărora au fost implicaţi tinerii: Marşul pentru Viaţă; Săptămâna Tineretului Ortodox (a şasea săptămână din Postul Mare); Marşul pentru Familie; Ziua Femeilor Mironosiţe; Pelerinajul Tinerilor; conferinţe; seri duhovniceşti; concursuri, pelerinaje, acţiuni de caritate ş.a.

Conştientizând faptul că tehnologiile informaţionale de ultimă generaţie au împânzit întregul glob pământesc, iar reţeaua globală Internet este prezentă mai nou în fiecare a treia casă din Republica Moldova, au fost create portaluri creştin ortodoxe (www.tineretulortodox.md; www.altarulcredintei.md), prin intermediul cărora se vine în ajutorul tineretului de astăzi, atât de derutat şi atât de nepregătit pentru o viaţă creştină în Duhul Evangheliei lui Hristos ${ }^{7}$.

\section{Concluzii}

Capela „Întâmpinarea Domnului” reprezintă o oază de linişte şi un spaţiu al renaşterii pentru tineri, aici găsind sprijin şi încurajări din partea preoţilor slujitori. Preotul joacă un rol considerabil în viaţa

\footnotetext{
${ }^{6}$ Ionuţ Bursuc, Pastoraţia tinerilor ca misiune a Bisericii, www.doxologia.ro.

${ }^{7} \mathrm{http}$ ://tineretulortodox.md/2011/04/ce-asteapta-biserica-de-la-tineretul-de-astazi.
} 
tinerilor, dând dovadă de înţelegere, răbdare şi îngăduinţă faţă de cei pe care îi asistă şi îi îndrumă spiritual, astfel ajutându-i să-şi găsească liniştea sufletească. În calitate de duhovnic preotul devine părtaşul neliniştilor, îndoielilor şi problemelor tinerilor cu care vine în contact. Biserica îi aşteaptă pe tineri să se angajeze de asemenea în misiunea ei de propovăduire a credinţei şi de slujire a semenilor. Tinerii sunt dinamici, au iniţiative, dar şi forţa necesară pentru a le duce la împlinire. Trebuie să acordăm o atenţie deosebită enoriaşilor tineri, care trebuie atraşi spre lucrarea amplă a Bisericii, spre folosul lor şi al semenilor.

Comunicarea preotului cu studenţii trebuie să se desfăşoare cu dragoste, cu căldura inimii, cu jertfire de sine, cu smerenie şi blândeţe, având în memorie modelul viu şi sacru - modelul Marelui Învătător, Domnul nostru Iisus Hristos.

Deşi se resimt schimbări în diverse domenii ale activităţii umane, Hristos şi învăţătura sa rămân aceleaşi după mai bine de două milenii. Esenţa, dogma, rămâne neschimbată până astăzi, atâta doar că modalitatea apropierii sau însuşirii celor dumnezeieşti se schimbă de la epocă la epocă, de la societate la societate. Fiecare se apropie în felul său de acea "Cale, Adevăr şi Viaţă". Important să ne îngrijim de cei în creştere, încât să avem o societate sănătoasă şi integră. 


\section{Bibliografie}

- Bezviconi, Gh., Biserica „Sf. Teodor Tiron”- „Ciufli”. În: „Din trecutul nostru”, Chişinău, 1934.

- Bursuc, Ionuţ, Pastoraţia tinerilor ca misiune a Bisericii, www.doxologia.ro.

- Moşin, O., Candu, T., Unele aspecte privitoare la zidirea şi sfinţirea bisericii „, Intâmpinarea Domnului” din Chişinău, în: „Educaţie şi viaţă spirituală în Basarabia. Tradiţii şi perspective”, Chişinău: CEP USM, 2015.

- Moşin, Octavian, Vrednici slujitori la biserica „Întâmpinarea Domnului”, în: „Educaţie şi viaţă spirituală în Basarabia. Tradiţii şi perspective", Chişinău: CEP USM, 2015.

- $\quad$ Sârbu, Preotul Ilie, Catehizarea copiilor şi tineretului, obiectiv prioritar al Bisericii, în „Altarul Banatului”, an. I (40), mai-iunie 1990, nr. 5-6.

- Освящение места для иеркви при Кишиневском Духовном училище 18 апреля сего 1879 года. В: КЕВ, №10, 1879.

\section{Adrese web}

- $\quad$ http://tineretulortodox.md/2011/04/ce-asteapta-biserica-de-la-tineretulde-astazi

- http://tineretulortodox.md/2011/04/pr-octavian-mosin-Clucrul-cutineretul-trebuie-sa-fie-o-prioritate-a-bisericii-ortodoxe

- http://tineretulortodox.md/2015/08/in-perioada-7-9-august-s-adesfasurat-in-premiera-tabara-de-vara-la-bastina-parintelui-sofianboghiu-cuconestii-vechi

- $\quad$ http://tineretulortodox.md/2016/04/s-a-dat-start-saptamanii-tineretuluiortodox-la-usm

- $\quad$ www.masterateortodoxe.blogspot.com 